taken in these matters in Australia. The Royal Societies of South Australia and New South Wales, the advisory committee re Fisheries and Game Acts in Victoria, and the Linnean, Zoological, and Animals' Protection Societies of New South Wales are all taking an active part in furthering the good cause. An influential deputation, headed by Prof. W. Baldwin Spencer, F.R.S., has already waited upon the Prime Minister of the Commonwealth, on August 4, in regard to the prohibition of the exportation of the slinins and plumes of Australian birds, and was most favourably received. It must not be supposed, of course, that nothing has already been done to secure the preservation of the native fauna of Australia; this is by no means the case. Some of the most interesting animals, such as the platypus and the lyre bird, have, we believe, been more or less protected for a long time, but it is felt, and rightly, that existing legislation is not sufficient, and that if the native fauna is not to disappear in the near future, much more vigorous action must be taken. We wish the new movement in this direction every success, and cannot doubt that it will be followed by excellent results.

Arthur Dendy.

\section{PROF. WILLIAM EDWARD AYRTON, F.R.S.}

$\mathrm{O}$ Sunday, November 8 , Prof. Ayrton died at the age of sixty-one. During the last four years he was in danger on account of excessive bloodpressure. The immediate cause of death was influenza, followed by bronchitis and heart failure.

$\mathrm{He}$ was the son of an able barrister and the nephew of the Rt. Hon. Acton Ayrton, a Minister in Gladstone's Government from 1869 to 1874 . I have before me the history of the Ayrton family for the last three hundred years, a family of able lawyers, musicians, surgeons, clergymen, university dons, and schoolmasters. He went to University College School, London, where he gained numerous prizes; at University College he gained the Andrews exhibition in 1865 and the Andrews scholarship in $1866 . \mathrm{He}$ passed the first B.A. examination with honours, and then became a pupil of Lord Kelvin in preparation for the Indian Telegraph Service. His eulogistic account of how Lord Kelvin dealt with his students, published in the Times about the beginning of this year, was greatly praised in Nature a short time ago. In style and force it will compare favourably with anything written in the English language. He was not only a fine writer, he was also a brilliant speaker. He seldom needed notes in speaking. Twenty years ago, at the Paris Exhibition, he gave a long lecture in French, using no notes, and French critics described it as being nearly perfect in style and enunciation. In India he did good work with the late Mr. Schwendler, and became electrical superintendent of the Telegraph Department. In 1872-3 he was on special duty in England, and acted also for Lord Kelvin and Prof. Jenkin, the engineers of the Great Western Telegraph Cable. From 1873 to 1878 he was professor of natural philosophy and instructor in telegraphy in the Imperial College of Engineering, Tokio, Japan.

I gave a short account of Ayrton's Japanese laboratory in a paper read before the Society of Arts in January, I88o. I venture to think that nobody interested in the history of scientific education can afford to neglect that paper. It describes the educational ideas which had gradually been developed in Japan. At Glasgow and Cambridge and Berlin there were three great personalities, but, except for these, the laboratories of Kelvin, of Maxwell, and of
Helmholtz were not to be mentioned in comparison with that of Ayrton. When I went to Japan in 1875 , what I found were fine buildings, splendid apparatus, carefully chosen and often designed by himself, and earnest, diligent students; I found also a neverresting, energetic, keen-eyed chief of great originality and individuality. It is no wonder that Maxwell jestingly said that the electrical centre of gravity had shifted towards Japan. It must be remembered that at that time there were not half-a-dozen people in Great Britain who had experimented in electricity.

Before 1875 he had published papers on telegraphy; after 1875 his investigations were mainly on electrical phenomena, sometimes without, but oftener with, a practical bearing on engineering.

From 1879 to I884 Ayrton was professor of applied physics at the City and Guilds Technical College, Finsbury. It may already be forgotten that the system of instruction created there was radically different from anything which previously existed. It is now to be found in every technical college of this country. Students learnt by actually doing things in the laboratories and workshops. The most important thing leading to success was that there were no outside examiners. Hitherto professors had merely shown experiments at the lecture table. In one or two mechanical laboratories a few students looked on whilst the professor broke specimens with a 2oo-ton testing-machine or made tests on a steam engine. Only a few volunteer students had a chance of making experiments in physics anywhere. Ayrton gave interesting work to all students, and induced them to think things out for themselves. The motors and dynamos and other contrivances which were tested were not so small as to be toys, and they were not so large but that they could be left in charge of the average student without fear of disaster. The preliminary work was particularly Ayrton's invention, and as to this his book on Practical Electricity ought to be consulted. He said :in the study of mechanics and other parts of science we deal with weight, inertia, stress, colour, \&c., and a boy's senses have made such things tangible. But in electricity we deal with something almost abstract, and there must be a regular training which will make the things which we call current and voltage and resistance and magnetic induction just as tangible to the student as weight is.

Again, Ayrton never tried to create the perfect engineer. He aimed at creating a learner, a person with developed common sense, a man who would learn engineering when he had the chance of practice, a man whose education would go on until he died, a man who could use books, a man fond of reading. It is difficult now to say how much of his system is due to colleagues like Armstrong and myself. We had the same ideas, we never quarrelled, we never seemed to differ in opinion; on any given question we seemed always to come to the same conclusions. No mere chemist taught chemistry, no mere mathematician taught mathematics, no mere physicist taught physics, no mere specialist taught anything at that college. Practical and descriptive geometry and graphics were taught, and almost no deductive geometry or geometrical conics. Ninety per cent. of the usual work in algebra and trigonometry was put aside as unnecessary trickery. Analytical conic sections gave place to the calculus study of curves in general. Before 1879 squared paper was expensive; in I879 Ayrton arranged that it could be bought at sixpence a quire. Every subject was taught through the other subjects. I am afraid that the average student would have failed to pass any outside examination in any of the subjects, but he had a wonderful power of using on any new 
problem his very thorough acquaintance with a few fundamental principles.

No marks were ever given for lecture notes, but rough laboratory notes and finished accounts of laboratory work in good English, with elaborate sketches and squared-paper curves, were thought most important. When a hundred students pass through laboratories of no large dimensions in one week, some system must be adopted, and the education cannot be ideally perfect, especially when the number of instructors is limited. But great encouragement was given to any student who adventured and discovered things of which he had not been told anything. Advanced students had fine opportunities for original research.

From 1884 until he died Ayrton was professor of electrical engineering at the City and Guilds Central College; South Kensington. The laboratory here became a sort of developed combination of that at Finsbury and the one in Japan. In my opinion, there is no electrical laboratory in the world that can compare with the Kensington laboratory, whether we look at it from the educational or from the research point of view. He always said that much of its success was due to the helpfulness of Mr. Mather.

In dealing with students, that earnestness and enthusiasm and inspiration, that training in scientific method, that sympathy and helpfulness for others which he received from Lord Kelvin, he handed on to many thousands of pupils, and they in turn are handing them on to new generations.

"'The Electricians' Directory" speaks of about ${ }_{5} 50$ papers published, usually in collaboration with myself, Mather, and others, in the Proceedings and Transactions of the Royal Society, Physical Society, Institution of Electrical Engineers, and other societies, giving the titles of the most important, and it gives the names of some of the numerous inventions with which Ayrton alone or with others has benefited the world. The time from 1879 to $\mathrm{I} 884$ was a particularly happy one. There are now hundreds of schools where men may learn electrical science; in most of them his pupils are teaching. There are now thousands of electrical engineers in whose employment a man can obtain experience. But at that time there was only one school, there was almost only one office in which and there was almost only one engineer in whose service, education and experience could be found. Every young man of promise, every engineer with ambition, was attracted from Germany, America, and elsewhere to the place where new discoveries and new inventions were the order of the day. It was a glorious time, that pioneering time when everything planted was fruitful, when everything tried was successful. Those discoveries are now such common knowledge, those inventions are such usual parts of all electrical machinery, that nobody dreams of mentioning their author's name in connection with them.

I remember once, in 1886 , sitting at a meeting of the Institution of Electrical Engineers beside Prof. Ayrton, and, looking over the large audience, I was able to say that nearly three-quarters of the people present were Ayrton's old students.

He loved the Institution of Electrical Engineers, and it was no wonder, for it was the mirror of his life. It gave a setting and a value to all his life's work and all he cared for. It gave a scope for that energy, that earnestness, that untiring industry, that hatred of inaction which was his most intense characteristic. He was a member of it almost from the beginning; his speeches during discussions form some of the best reading in its proceedings; he was a diligent attender at general meetings, at council meetings, and at meetings of the numerous committees. His love for it was that of a nurse or mother for the boy whom she has seen grow up to splendid manhood.

Since 1879 , when he lectured on electrical transmission of power at Sheffield, Prof. Ayrton delivered many popular lectures, and each of them may be said to have been epoch-making. He acted on many juries and congresses. He was president of Section A of the British $A$ ssociation in 1898 , president of the Physical Society in 1890 , president of the Institution of Electrical Engineers in I892. He became a Fellow of the Royal Society in I88I, and in I90I he was awarded a Royal medal by the hoyal Society for his scientific work.

His first wife was his cousin, Matilda Chaplin, one of the famous pioneering Edinburgh medical students; their daughter Edith, now Mrs. Israel Zangwill, was born in Japan. His second wife is well known as the only woman member of the Institution of Electrical Engineers; she was awarded the Hughes medal of the Royal Society for her scientific work in I906; their daughter Barbara has already published a physiological investigation.

When I first knew him in Japan the motto printed on his notepaper was "Energy." It was his motto through life, or rather his motto was " Earnestness."

He had a keen sense of justice and a high regard for truth. His mere presence often caused the tone of conversation to be raised. The ideals towards which he worked incessantly were noble ideals. In his own lifetime great progress had been made towards their realisation, but occasionally he was despondent, particularly towards the end, when his ailing body could not respond to his vehement spirit. He could not see that all the noble things for which he had worked were being worked for now by numerous energetic young men, most of whom had been inspired by himself. It was sad to watch him towards the end, the active mind warring with the weak body. I felt often that I wanted to say with Kent in the old play, "O, let him pass! He hates him that would upon the rack of this rough world stretch him out longer."

\section{John Perry.}

\section{NOTES.}

Sir William Ramsay, K.C.B., F.R.S., and Dr. G. W. Hill have been elected corresponding members of the Bavarian Academy of Sciences.

M. Lours-Félix Henneguy, professor of comparative embryogeny in the Collège de France, has been elected a member of the Paris Academy of Sciences.

Mr. James Swinburne, F.R.S., has been elected president of the Junior Institution of Engineers, in succession to the late M. Gustave Canet.

We learn from Science that the Nichols medal of the American Chenical Society has been awarded to Prof. W. A. Noyes, of the University of Illinois, and Dr. H. C. P. Weber, for their researches on the atomic weight of chlorine.

THe Royal Statistical Society offers the "Howard medal " (bronze) and a grant of $20 l$. for the best essay on a statistical study of infantile mortality in Great Britain and Ireland and of its causes. The competition is open, and is not limited to Fellows of the Statistical Society. Essays must be sent in before June 20, 1909.

THE eighty-third Christmas course of juvenile lectures, founded at the Royal Institution in 1826 by Michael Faraday, will be delivered this year by Prof. William Stirling, his subject being "The Wheel of Life." The NO. 2038, VOL. 79] 